\title{
New host records of Ixodes luciae (Acari: Ixodidae) in the State of Para, Brazil
}

\author{
Registros de novos hospedeiros para Ixodes luciae (Acari: Ixodidae) no estado do Pará, Brasil \\ Hermes Ribeiro Luz ${ }^{1}$; João Luiz Horacio Faccini ${ }^{1 *}$; Gabriel Alves Landulfo'; Janio dos Santos Sampaio; \\ Sócrates Fraga Costa Neto ${ }^{1}$; Kátia Maria Famadas ${ }^{1}$; Valeria Castilho Onofrioº ${ }^{2}$ Darci Moraes Barros-Battesti ${ }^{2}$ \\ ${ }^{1}$ College of Animal Parasitology, Federal Rural University of Rio de Janeiro - UFRRJ, Seropédica, RJ, Brazil \\ ${ }^{2}$ Laboratory of Parasitology, Butantan Institute, São Paulo, SP, Brazil \\ Received February 5, 2012 \\ Accepted March 23, 2012

\begin{abstract}
The aim of this paper is to record new hosts for Ixodes luciae Sénevet in the State of Para, Brazil, and present a case of malformation (teratogeny) in a nymph of this species. The new host records are Marmosa murina (parasitized by females) and Philander opossum (parasitized by nymphs). One of these nymphs showed malformation in the posterior margin of the opisthosoma resulting in a heart shaped posterior end.
\end{abstract}

Keywords: I. luciae, new hosts, teratogeny, Marmosa murina, Philander opossum, Brazil.

\section{Resumo}

O objetivo deste trabalho foi registrar novos hospedeiros para Ixodes luciae Sénevet no estado do Pará, Brasil, e um caso de malformação em uma ninfa dessa espécie de carrapato. Os novos hospedeiros são Marmosa murina (parasitado por fêmeas) e Philander opossum (parasitado por ninfas). Uma dessas ninfas apresentou uma malformação na parte posterior do opistossoma em forma de coração.

Palavras-chave: I. luciae, novos hospedeiros, teratogenese, Marmosa murina, Philander opossum, Brasil.

Small mammals are the main hosts for immature stages of ticks and other groups of ectoparasites and are reservoirs for numerous pathogens (LINARDI; GUIMARÃES, 2000; GUGLIELMONE; NAVA, 2011). Rodents, marsupials and bats present an enormous ability to adapt to anthropized rural and urban ecosystems. They are considered potential transmitters of pathogens to domestic animals and humans, both directly and indirectly, through vectors. Therefore, adequate knowledge of the host-parasite relationship between hosts and ticks is critical to the understanding of their importance as possible agents of zoonosis. In Brazil, ticks of the genus Ixodes are represented by eight species, most of them parasitizing small mammals, with just two species occurring exclusively on birds (LABRUNA et al., 2003). The species Ixodes luciae Sénevet, 1949 is found in several countries of the Neotropical region, from Argentina to southern Mexico, with records in Bolivia, Brazil, Colombia, Costa Rica, Ecuador, French Guiana, Guatemala, Honduras, Mexico, Nicaragua, Panama, Peru, Suriname, Trinidad and Tobago and Venezuela (GUGLIELMONE et al., 2003). Its distribution in Brazil includes the states of Para, Rondonia,

\footnotetext{
*Corresponding author: João Luiz Horacio Faccini

Departamento de Parasitologia Animal, Universidade Federal Rural do Rio de

Janeiro - UFRRJ, CEP 23851-970, Seropédica, RJ, Brasil

e-mail: faccinijlh@ufrri.br
}

Amazonas, Mato Grosso do Sul, and Acre, where it can be often found on small rodents and marsupials (ONOFRIO et al., 2010; GUGLIELMONE et al., 2011). These authors have described the immature stages of $I$. luciae and redescribed adults after examination of specimens of this species deposited at the Brazilian Collections - IBSP (Coleção Acarológica do Instituto Butantan), CNC-FMVZUSP (Coleçẫo Nacional de Carrapatos da Faculdade de Medicina Veterinária e Zootecnia da USP), MPEG (Museu Paraense Emilio Goeldi), INPA (Instituto de Pesquisas da Amazônia), IOC (Instituto Oswaldo Cruz - FIOCRUZ) - as well the material at the United States National Tick Collection (USNTC). According to these sources, adults of I. luciae are primarily found on marsupials, while immature stages parasitize marsupials and rodents.

The following records of small mammals parasitized by this tick species in different municipalities of the State of Para, including the accession numbers in those collections are: Didelphis aurita - IBSP 6853 (1 Female, Maraba, without data of collection), INPA 16 (1 Male, without data of collection), and INPA 17 (3 Males, Tucurui, 20/VI/1980); Didelphis sp. - IBSP 6849 (1 Male, Belem, 08/15/1969) and 6852 (4 Males and 6 females, Belem, 08/17/1970); Philander opossum - IBSP 3845a (2 Males and 1 female, Igarape-Açu, 04/13/1955); rat - MPEG 09 (1 Female, São João de Pirabas, 12/22/1992), MPEG 30 (2 Males, Tucurui, 03/30/1984), and CNC-FMVZUSP 1089 (1 Female, Maraba, 12/16/2007). 
The aim of this paper was to record additional cases of parasitism by I. luciae and the malformation in a nymph collected from small wild mammals in three different regions of the State of Para, Brazil.

The collections were performed in 2009 and 2010 in the municipalities of Abaetetuba ( $1^{\circ} 43^{\prime} \mathrm{S}$ and $\left.48^{\circ} 52^{\prime} \mathrm{W}\right)$, Igarape - Miri ( $1^{\circ} 58^{\prime} \mathrm{S}$ and $\left.48^{\circ} 57^{\prime} \mathrm{W}\right)$ and Val De Cans ( $1^{\circ} 23^{\prime} \mathrm{S}$ and $\left.28^{\circ} 57^{\prime} \mathrm{W}\right)$. A total of 280 traps, 140 Sherman-type and 140 Tomahawk-type, were set in 11 transects in forested areas in each municipality. The transects were named: tracks A and B (patch of woods, trees about 4 meters and dense understory; tracks $\mathrm{C}$ and $\mathrm{D}$ (secondary forest type barns with the presence of a large clearing in the vicinity); tracks E, F, G, H, I, and J (presence of many large trees and undergrowth preserved); and Barn (located inside a remnant of the Amazon Forest). Traps were left in transects for periods ranging from one to five consecutive nights, totaling an overall sampling effort of 827 traps/nights. All captured animals were taken to the field laboratory to be properly inspected for ticks. Small mammals captured were weighed and anesthetized with a combination of ketamine and xylazine in a 1:1 ratio, using international recommended doses of $10 \mathrm{mg} / \mathrm{kg}$. All marsupials captured were kept in the laboratory until complete recovery from anesthesia and then released in the site of capture. All hosts were collected with permission from the Brazilian Institute of Natural Resources (IBAMA), Process 1264-2/2009. The identification of I. luciae was based on Onofrio et al. (2009, 2010).

During this study, 76 specimens of small mammals were captured, belonging to two orders, four families and nine species (Table 1). The order Didelphimorphia was represented only by the family Didelphidae, whereas the order Rodentia was represented by three families: Echimyidae, Dasyproctidae, and Muridae. The order Didelphimorphia was, by far, the most abundant one, with $62(82 \%)$ specimens distributed in seven species parasitized by I. luciae (Table 1). The presence of only I. luciae and its preference for the Didelphidae in the region studied corroborates the results by Díaz et al. (2009), who also found only one single tick species, I. luciae parasitizing didelphids along the Iquitos-Nauta highway,

Table 1. Small mammals parasitized by Ixodes luciae in three different collection sites in the State of Para, Brazil.

\begin{tabular}{|c|c|c|c|c|}
\hline Sites & Hosts & Examined/Infested & Nymphs & Adults \\
\hline \multirow[t]{13}{*}{ Val De Cans } & DIDELPHIMORPHIA & & & \\
\hline & Didelphidae & & & \\
\hline & Philander opossum & $23 / 3$ & 3 & 0 \\
\hline & Didelphis sp. & $6 / 0$ & 0 & 0 \\
\hline & Gracilinanus sp. & $6 / 0$ & 0 & 0 \\
\hline & Marmosa murina & $1 / 1$ & 0 & $3 \mathrm{~F}$ \\
\hline & RODENTIA & & & \\
\hline & Echimyidae & & & \\
\hline & Proechimys sp. & $1 / 0$ & 0 & 0 \\
\hline & Muridae & & & \\
\hline & Rattus rattus & $3 / 0$ & 0 & 0 \\
\hline & Dasyproctidae & & & \\
\hline & Dasyprocta agouti & $1 / 0$ & 0 & 0 \\
\hline \multirow[t]{10}{*}{ Abaetetuba } & DIDELPHIMORPHIA & & & \\
\hline & Didelphidae & & & \\
\hline & Philander opossum & $3 / 0$ & 0 & 0 \\
\hline & Didelphis marsupialis & $5 / 0$ & 0 & 0 \\
\hline & Marmosops sp. & $1 / 0$ & 0 & 0 \\
\hline & Metachirus sp. & $1 / 0$ & 0 & 0 \\
\hline & Marmosa murina & $1 / 0$ & 0 & 0 \\
\hline & RODENTIA & & & \\
\hline & Muridae & & & \\
\hline & Rattus rattus & $1 / 0$ & 0 & 0 \\
\hline \multirow[t]{11}{*}{ Igarape-Miri } & DIDELPHIMORPHIA & & & \\
\hline & Didelphidae & & & \\
\hline & Philander opossum & $4 / 1$ & 7 & 0 \\
\hline & Didelphis marsupialis & $6 / 0$ & 0 & 0 \\
\hline & Marmosops sp. & $1 / 0$ & 0 & 0 \\
\hline & Marmosa murina & $4 / 2$ & 0 & $6 \mathrm{~F}$ \\
\hline & RODENTIA & & & \\
\hline & Echimyidae & & & \\
\hline & Proechimys sp. & $3 / 0$ & 0 & 0 \\
\hline & Dasyproctidae & & & \\
\hline & Dasyprocta agouti & $5 / 0$ & 0 & 0 \\
\hline
\end{tabular}


Department of Peruvian Amazon, in Loreto. However, the striking difference between the prevalence found by Díaz et al. (2009) - 262 (70\%) infested in 370 didelphids examined, and the prevalence found in this study - seven (20\%) infested in 35 didelphids examined, occurred probably due to the difference in the number of didelphids trapped in both studies. The absence of other species of ticks is rather surprising, especially because none of the five agoutis captured were parasitized by ticks, as these rodents are reported as hosts for immature Amblyomma and I. fuscipes in the Amazon region (LABRUNA et al., 2005). A total of 19 ticks were collected, 10 nymphs on four P. opossum males and nine females on three $M$. murina females (Table 1). One of the nymphs collected from $P$. opossum showed malformation in the posterior margin of the opisthosoma (teratogeny), resulting in a heart shaped posterior end, instead of rounded opisthosoma. Morphological malformations, although rare, have been reported in several species of ixodids (LABRUNA et al., 2002). Results showed that parasitism by nymphs of $I$. luciae on P. opossum and females in $M$. murina are new host records for the State of Para, thus extending the results published by Díaz et al. (2009) and Onofrio et al. (2010).

\section{Acknowledgements}

This research was supported by CNPq, FAPESP and CAPES.

\section{References}

Díaz MM, Nava S, Guglielmone AA. The parasitism of Ixodes luciae (Acari: Ixodidae) on marsupials and rodents in Peruvian Amazon.
Acta Amaz 2009; 39(4): 997-1002. http://dx.doi.org/10.1590/S004459672009000400029

Guglielmone AA, Estrada-Peña A, Keirans JE, Robbins RG. Ticks (Acari: Ixodida) of the Neotropical zoogeografic region. Atlanta: Houten; 2003.

Guglielmone AA, Nava AA. Rodents of the subfamily Sigmodontinae (Myomorpha: Cricetidae) as hosts for South American hard ticks (Acari Ixodidae) with hypotheses on life history. Zootaxa 2011; 2904: 45-65.

Guglielmone AA, Nava S, Díaz MM. Relationships of South American marsupials (Didelphimorphia, Microbiotheria and Paucituberculata) and hard ticks (Acari: Ixodidae) with distribution of four species of Ixodes. Zootaxa 2011; 3086: 1-30

Labruna MB, Ribeiro AF, Cruz MV, Camargo LM, Camargo EP. Gynandromorphism in Amblyomma cajennense and Rhipicephalus sanguineus (Acari: Ixodidae). J Parasitol 2002; 88(4): 810-811. PMid:12197141.

Labruna MB, Silva MJ, Oliveira MF, Barros-Battesti DM, Keirans JE. New records and laboratory-rearing data for Ixodes schulzei (Acari: Ixodidae) in Brazil. J Med Entomol 2003; 40(1): 116-118. PMid:12597665. http://dx.doi.org/10.1603/0022-2585-40.1.116

Labruna MB, Camargo LMA, Terrassini FA, Ferreira F, Schumaker TTS, Camargo EP. Ticks (Acari: Ixodidae) from the state of Rondônia, western Amazon, Brazil. Syst Appl Acarol 2005; 10: 17-32

Linardi PM, Guimarães LR. Sifonápteros do Brasil. São Paulo: Museu de Zoologia da USP; 2000.

Onofrio VC, Barros-Battesti DM, Labruna MB, Faccini JLH. Diagnoses of and illustrated key to the species of Ixodes Latreille, 1795(Acari: Ixodidae) from Brazil. Syst Parasitol 2009; 72(2): 143-157. PMid:19115087. http:// dx.doi.org/10.1007/s11230-008-9169-z

Onofrio VC, Labruna MB, Faccini JLH, Barros-Battesti DM. Description of immature stages and redescription of adults of Ixodes luciae Sénevet (Acari: Ixodidae). Zootaxa 2010; 2495: 53-64. 